\title{
The Productivity and Structure of Sage (Salvia L.) Populations in the Territories of Lesser Caucasus Range
}

\author{
Saadat Guliyeva1 , Sabina Akhundova2, Ramiz Alakbarov³, Hilal \\ Qasimov4
}

${ }^{1,2}$ Azerbaijan State Agricultural University, Ganja c.

${ }^{3}$ ANAS Bioresouces Institute, ${ }^{4}$ Nakhchivan State University, Nakhchivan c.

\begin{abstract}
Salvia species are selected in the fitocenological complexes of the regions of Lesser Caucasus range (Nakhchivan AR and north-east regions of LC). In these populations, the fitocenological state of 4 species (S.limbata, S.sclarea, S.verticulata vo S.tesquicola) which are belonged to the breed, is estimated,their reserves are found out and the dynamics of the productivity in the ontogeny is determined.It is known that, in the populations, individuals belonged to the $\mathrm{g}_{1} \mathrm{v} \mathrm{g}_{2}$ phases of the ontogeny are more and at the same phase, the plant gives more product. Sage (Salvia L.) breed is one of the representatives of Lamiaceae (Lamiaceae Lindl.) family.27 species of the breed spread in the flora of Azerbaijan. 19 species of them spread in the flora of the Nakhchivan AR, and 12 species in the central, northern and eastern regions of Lesser Caucasus.Two of these territories - central and south are under Armenian occupation, that is why, only the population structure of the species in the north-east is found out. 9 species from 19 species which are come across in the flora of the Nakhchivan AR are merely characteristic for the region. 4 species which are come across in the north-east regions of Lesser Caucasus and in the autonomous republic, are selected and each of the species is in the surround of Lesser Caucasus range[nakh cons]. Referring to the literature,among them, S.limbata is not noted in the north-east regions of LC, but during the reserches, the same species are come across in the lower and central mountainous zones of the territory and in the dry stony-rocky slopes. It is a xerophyte plant, the territory is a new spreading field for it. In "Tartar" region, its new population is noted. Its other populations are noted in "Goranboy" and "Dashkesen" regions. 5-6 populations of the plant are setted in the Nakhchivan AR ( in "Babak", "Sherur", "Kengerli" regions).From the other selected three species, S.verticulata is come across in the all regions of Azerbaijan, S.tesquicola is in the Nakhchivan plain and "Goygol" region in the north of LC,and S.sclareais in the east of LC range ( in the "Shamkir" and "Gadabay" regions) and in the Nakhchivan highlands.
\end{abstract}

Keywords: Salvia, cenopopulation, plant reserve,productivity,age index,efficiency index.

The aim of the reserch is the determination of the fitocenological state and reserve of Salvia species which spread in the main fitocenological complexes of natural plants in the regions of Lesser Caucasus Range,as well as,the study of dynamic relation between the evaluation of cenopopulations and productivity.

\section{Materials and Methods}

In order to find out Salvia species, 10 populations were selected in 2014-2015. While the reseaching, 4 types of the plant area were determined(semidesert, mountain-xerophyte, heath, shrubbery), and S.limbata, S.tesquicola vo S.sclarea are come across in semidesert, mountain-xerophyte, heath fields. And
S.verticulata spreads in highland zones $(2500 \mathrm{~m}$ AMSL), in the riversides, meadow,mountainxerophyte fields and so on.It is almost polymorphous species and it is coincided everywhere.

Productivity of the plant is found out according to the common adopted methods [4,7,8,9]. The area of cenopopulations which is selected for studying the productivity of the species, is 2-4 hectare.For determining the reserve, special platforms are marked in the concrete fiels in which the species spread and model samples are selected.In each of the fields, the calculations are made for the evaulation of the plant cenopopulations in 25-30 platforms (1x1 size). Moreover, for calculating the reserve of the plant

This article is published under the terms of the Creative Commons Attribution License 4.0

Author(s) retain the copyright of this article. Publication rights with Alkhaer Publications.

Published at: http://www.ijsciences.com/pub/issue/2016-02/

DOI: 10.18483/ijSci.947; Online ISSN: 2305-3925; Print ISSN: 2410-4477 
raw, 15-20 models from each population are taken off and pulled out. The draf cover of the fields is calculated [6].

While evaluating the cenopopulations of the species, a number of methods are used in geobotanical reseaches: the spelling of the phytocenosis is based on B.A.Yursev [13], the naming of the fitocenotical complex is based on R.V. Kamelin [5].

The growth phases of the plant individuals are characterized according to the using of T.A.Rabotnov's and A.A.Uranov's discrete discription method of ontogeny.Vital forms of plants are carried out accoring to the diagnosis and keys of their ontogenetic states(Жукова, 1983; Жукова, Османова, 1997). The plant is noted in immatur (im), virgin $(v)$, young generative $\left(\mathrm{g}_{1}\right)$, mature generative $\left(\mathrm{g}_{2}\right)$ and old generative $\left(\mathrm{g}_{3}\right)$, subsenile (ss) and senile (s) periodsThe acquired results are analyzed by means of $\chi^{2}$ comparison criterion ( Закс, 1976).

During the reseach, 18 cenopopulations are used in the different phytocenoses. The materials are collected according to the applying method of common recieved populations(Ценопопуляции растений....., 1976; Изчение структуры......., 1986). Collecting of

1. The ageness index $(\Delta)$ (Uranov, 1975);

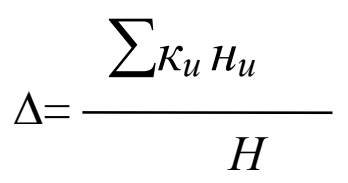

the materials is carried out in platforms which are situatedwith the systematic and discrete methods or in the transects.Putting the transects is as follows; they have to pass the field and characterize upper as well as lower fertility of each selected species. As the projection of the underground and overhead fields, the size of the practise fields is large from the three fitogen fields which determine the other elements of cenopopulations (Uranov, 1975). The size of the pratise fields for the plant is $50 \times 50 \mathrm{~cm}$, and the quantity of the fields is 15-25.

The investigated plant is pulled out from the fields and its ontogenetic state is determined.According to the recieved results, the spectrum of the ontogenetic state is prepared( "ageness spectrum" according to Uranov, 1975).

The evaluation of the nutrition condition of the plant is carried out with the using of ECOSCALE program complex (about the computer realisation..., 1991) according to Ramensky's ecologic scale(Экологическая оценка ..., 1956). The following population indexes are used as the integral characteristic of the demographic structure of the plant:

i-ontogenetic state $\mathrm{k}_{\mathrm{i}^{-}}$rate, $\mathrm{n}_{\mathrm{i}}$ - quantity of individuals, $\mathrm{i}$-the states of populations, $\mathrm{N}-$ total quantity of the individuals in populations.

2. The efficiency index (Животовский, 2001);

$$
\omega \frac{\sum H_{u} \cdot e_{u}}{\sum H_{u}}
$$

$\mathrm{n}_{\mathrm{i}}$ - the quantity of the plants, $\mathrm{i}$ - the state, $\mathrm{e}_{\mathrm{i}}$-the efficiency of the plant.

The type of the cenopopulations is determined with using the classification which is based on A.A. Uranov's and O.V. Smirnov's absolute maximum criterion and L.A. Jivatovsky's delta-omega classification of normal cenopopulations. Changing the form, N.V. Qlotov described the restoration index ( $\left.\dot{\mathrm{I}}_{\mathrm{b}}\right)$ [Жукова, 1995] as the correlation of the pregenetive individuals to the sum of the pregeneratives and generatives [Глотов, 1998].

$$
\dot{I}_{r}=\frac{i_{i=3}^{\sum N_{i}}}{\sum N_{i}}
$$

The aging index [Глотов, 1998]: 


$$
i_{a}=\frac{\sum_{i=9}^{\sum N_{i}}}{\sum N_{i}}
$$

Th efficiency index [Животовсий, 2001]:

$$
\omega=\mathrm{n} \mathrm{e}_{\mathrm{i}}
$$

$n_{i}-$ the quantity of the plants, $i$ - the state, $e_{i}$-the efficiency of the plant.

The effective ecologic density of the population $\left(\mathrm{M}_{\mathrm{e}}\right)$ is determined according to L.A.Jivatovsky [2001]

$$
\mathrm{M}_{\mathrm{e}}=\sum n_{i} \cdot \omega_{i}
$$

$n_{i}-$ the quantity of the plants, $\mathrm{i}-$ the state in a unit field, $\omega_{i}$ - the energetic efficiency of the populations

\section{The Experimental Section}

In two years, the populations ofspreading species are marked in each investigated type of the plant area.The researches are arranged in spring-autumn seasons, in all phases of the onthogenesis of the species, and their roles in the type of the plant area and fitocenological srtucture are found out.It is

\begin{tabular}{|c|c|c|c|c|}
\hline № & $\begin{array}{l}\text { The type of plant area and } \\
\text { formations }\end{array}$ & $\begin{array}{l}\text { The composition of the associations } \\
\text { (the main species are given) }\end{array}$ & 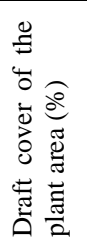 & 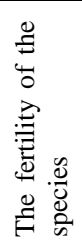 \\
\hline \multirow[t]{2}{*}{$\mathrm{I}$} & Semidesert & \multirow[b]{2}{*}{$\begin{array}{l}1 \mathrm{cp}: \text { Callycephalus nitens }+ \text { Salvia limbata }+ \\
\text { Atriplex turcomanica } \\
2 \mathrm{cp}: \text { Salvia limbata }+ \text { Camphorosma lessingi } \\
3 \mathrm{cp} \text { : Xeranthemum cylindraceae }+ \text { Salvia } \\
\text { verticulata }+ \text { Cousinia macroptera } \\
4 \mathrm{cp}: \\
\text { Artemisia fragrans }+ \text { Salvia sclarea }+ \\
\text { Ephemeretum }\end{array}$} & \multirow[t]{2}{*}{40} & \multirow[t]{2}{*}{$\mathrm{cop}_{2}$} \\
\hline & $\begin{array}{l}\text { 1. Callycephaluseta nitens } \\
\text { 2.Xeranthemumeta cylindraceae } \\
\text { 3.Artemisieta fragrans }\end{array}$ & & & \\
\hline \multirow[t]{2}{*}{ II } & Mountain-xerophyte, & \multirow{2}{*}{$\begin{array}{l}5 \mathrm{cp}: \\
\text { Salvia tesquicola+ Salvia sclarea }+ \\
\text { Camphorosma lessingi } \\
6 \text { cp: Salvia limbata }+ \text { Salvia virgata }+ \\
\text { herbosum }\end{array}$} & \multirow[t]{2}{*}{30} & \multirow[t]{2}{*}{ sol } \\
\hline & 1. Salvieta & & & \\
\hline \multirow[t]{2}{*}{ III } & Shrubbery & \multirow[b]{2}{*}{$\begin{array}{l}7 \text { cp: Zygophyllum fabago + Reaumuria } \\
\text { persica + Atraphaxis spinosa }+ \text { Salvia } \\
\text { verticulata } \\
8 \mathrm{cp}: \text { Thymus collinus }+ \text { Th. kotschyanus }+ \\
\text { Stachys inflata }+ \text { Acantholimon karelinii }+ \\
\text { Salvia verticulata }\end{array}$} & \multirow[t]{2}{*}{40} & \multirow[t]{2}{*}{$\mathrm{cop}_{1}$} \\
\hline & $\begin{array}{l}\text { 2. Zygophylleta fabago } \\
\text { 3. Thymusetum }\end{array}$ & & & \\
\hline \multirow[t]{2}{*}{ IV } & Heath & \multirow{2}{*}{$\begin{array}{l}9 \text { cp: Stipa capillatae }+ \text { Atraphaxis spinosa }+ \\
\text { Herbosa }+ \text { Salvia tesquicola } \\
10 \text { cp: Atraphaxis spinosa }+ \text { Caragana } \\
\text { grandiflora }+ \text { Salvia tesquicola }\end{array}$} & \multirow[t]{2}{*}{60} & \multirow[t]{2}{*}{$\mathrm{cop}_{3}$} \\
\hline & $\begin{array}{ll}\text { 4. } & \text { Stipeta capillatae } \\
\text { 5. } & \text { Atraphaxeta spinosae }\end{array}$ & & & \\
\hline
\end{tabular}
known that, in semidesert, mountain-xerophyte, heath types of plant area in which the species of the In Table1, the content of the botanical groups, in which Salvieta associations are extremely come across, their fertility, the spreading fields and their draft cover are marked.

Table 1.The fitocenological structure of the Salvieta populations in the areas of Lesser Caucasus range xerophyte ecologic group are investegated, Salvieta formations appear as the ecosystem engineers in Callycephaluseta nitenetosum, Camphorosmeta lessingosum Xeranthemumeta cylindraceosum, Cousiniameta macropterosum, Zygophyllumeta fabagosum, Atriplexeta turcomanicosum, Stipeta capillataosum and Caraganeta grandiflorosum and so on associations.In some cases, they spread within Thymuseta collinusum formations 
The Productivity and Structure of Sage (Salvia L.) Populations in the Territories of Lesser Caucasus Range

The composition of the ontogenecy in populations of Salvia species is given in Table 2.

The ontogenetic structure of the species in Salvia populations

\begin{tabular}{|c|c|c|c|c|c|c|c|c|c|c|c|c|}
\hline \multirow{2}{*}{$\begin{array}{l}\text { CP } \\
\text { Ont } \\
\text { perio }\end{array}$} & 1 & 2 & 6 & 3 & 7 & 8 & 4 & 5 & 9 & 10 & \multirow[t]{2}{*}{$\sum$} & $\%$ \\
\hline & \multicolumn{3}{|c|}{ S.limbata } & \multicolumn{3}{|c|}{ Salvia verticulata } & \multicolumn{2}{|c|}{ Salvia sclarea } & \multicolumn{2}{|c|}{$\begin{array}{l}\text { Salvia } \\
\text { tesquicola }\end{array}$} & & \\
\hline $\mathrm{J}$ & 11 & 5 & 2 & 9 & 1 & - & 3 & 3 & 2 & 7 & 54 & 11,66 \\
\hline im & 4 & 6 & 8 & 5 & 3 & - & 4 & 3 & 3 & 2 & 38 & 8,20 \\
\hline $\mathrm{V}$ & 5 & 7 & 2 & 10 & 3 & 6 & 5 & 9 & 7 & 6 & 60 & 12,95 \\
\hline $\mathrm{g}_{1}$ & 3 & 8 & 3 & 6 & 5 & 8 & 3 & 7 & 3 & 11 & 57 & 12,31 \\
\hline $\mathrm{g}_{2}$ & 13 & 14 & 5 & 4 & 16 & 12 & 6 & 7 & 2 & 9 & 88 & 19,00 \\
\hline $\mathrm{g}_{3}$ & 10 & 16 & 9 & 2 & 5 & 17 & 6 & 11 & 6 & 10 & 91 & 19,65 \\
\hline Ss,s & 9 & 10 & 3 & 12 & 10 & 8 & 1 & 12 & 3 & 7 & 75 & 16,19 \\
\hline$\sum$ & 55 & 66 & 32 & 48 & 43 & 51 & 28 & 52 & 26 & 52 & 463 & 100 \\
\hline
\end{tabular}

As to be seen from the table,all groups of the ontogenesis of the plant are mainly come across in populations, but in the $8^{\text {th }}$ population,juvenile and immature phases of the Salvia verticulata species do not appear (diag. 1-4).

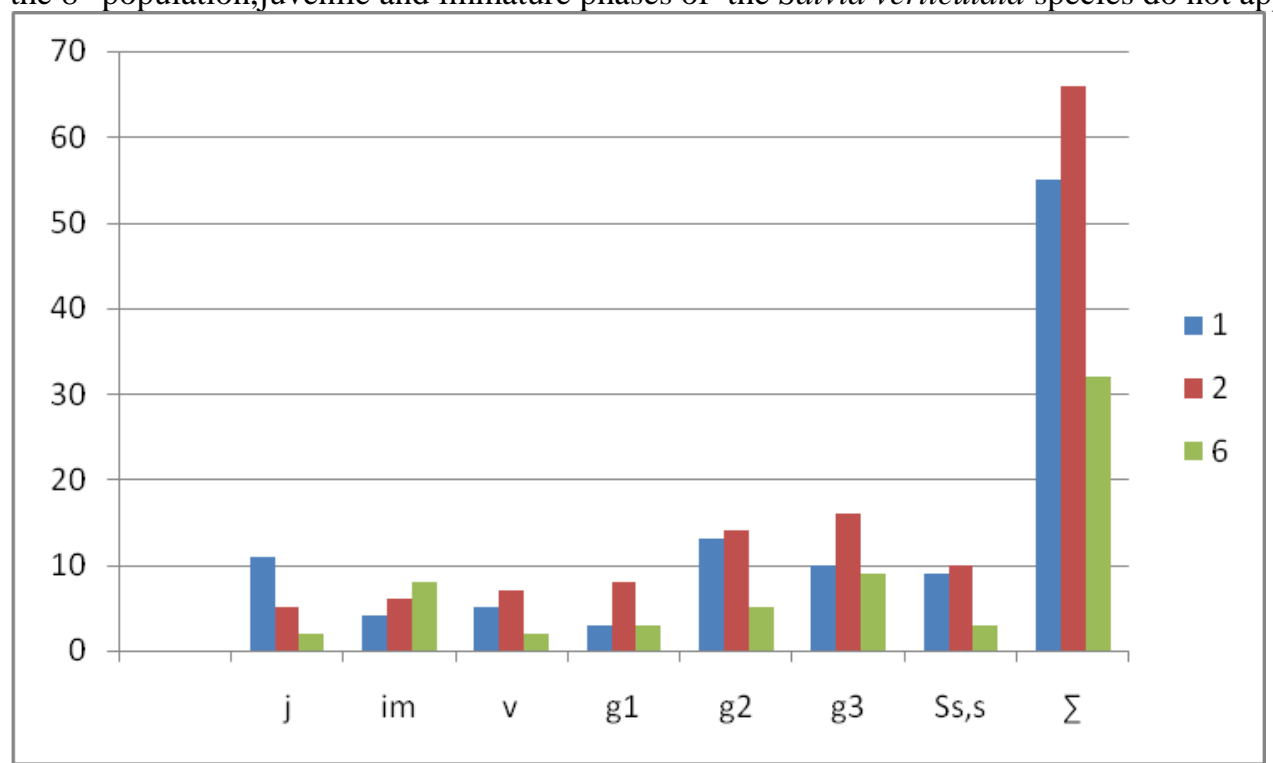

Diag 1. Ontogenetic structure of S.limbata species

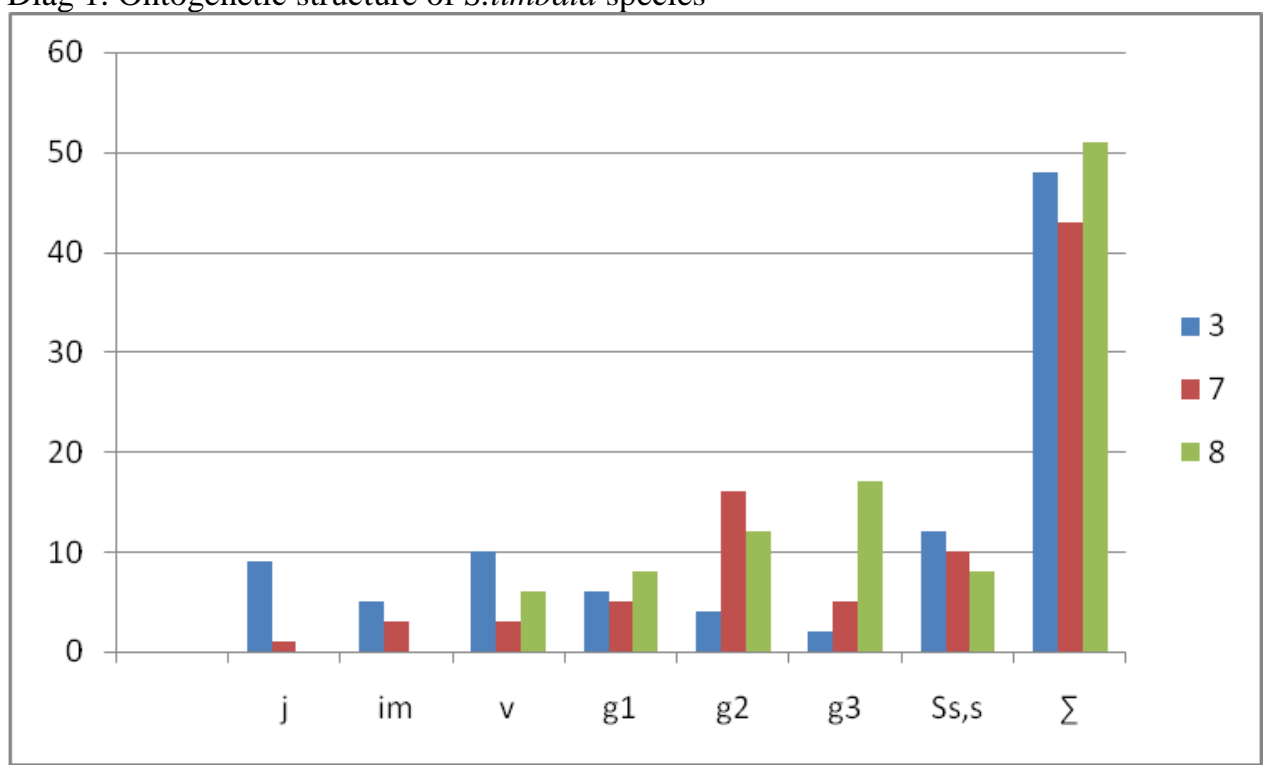

Diag 2. Ontogenetic structure of Salvia verticulata species 
The Productivity and Structure of Sage (Salvia L.) Populations in the Territories of Lesser Caucasus Range

It is seen from the diagrams that the fertility of the Salvia species appears mainly in the $\mathrm{g} 1-\mathrm{g} 3$ phases of the ontogenesis.

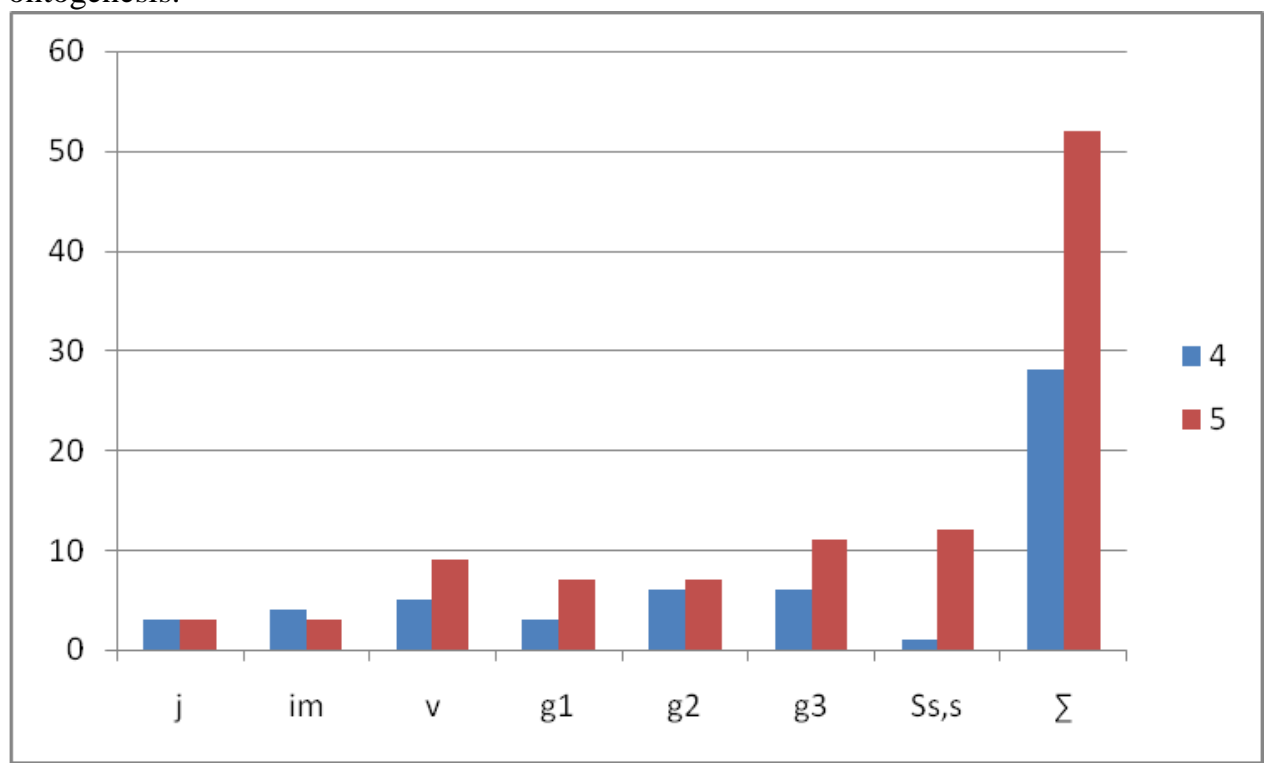

Diag 3. Ontogenetic structure of Salvia sclarea species

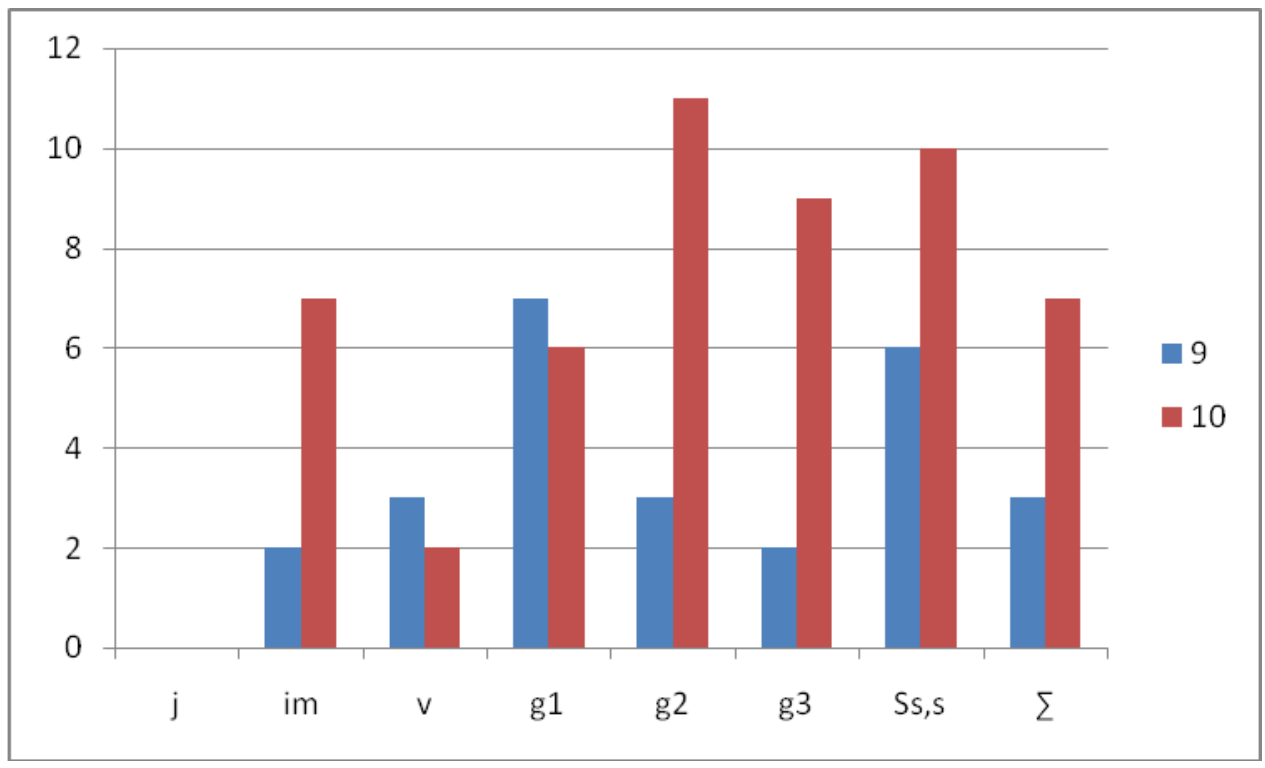

Diag 4. Ontogenetic structure of Salvia tesquicola species

During reseaching, the age, efficiency, aging and restoration degrees of the species are calculated according to the methods.It is seen from the table that the aging is mainly characterized in s-ss phases with the majority of the individuals. The restoration does not have the same nature in different years. It is explained with the quantity of the sunny and rainy days of the year ( tab.3). 
Table 3:The structure of the cenopopulations

\begin{tabular}{|c|c|c|c|c|c|c|c|c|c|c|c|}
\hline \multirow{2}{*}{\multicolumn{2}{|c|}{ № CP }} & \multirow{2}{*}{$\begin{array}{l}\text { The type of } \\
\text { CP }\end{array}$} & \multicolumn{5}{|c|}{ The growth phases of the ontogenesis , $\%$} & \multicolumn{4}{|c|}{ Indexes } \\
\hline & & & $\mathrm{J}$ & im & $\mathrm{V}$ & $\mathrm{g}_{1}-\mathrm{g}_{3}$ & ss, s & $\Delta$ & $\Omega$ & $\dot{\mathrm{I}}_{\mathrm{a}}$ & $\dot{\mathrm{I}}_{\mathrm{r}}$ \\
\hline$\underset{\overbrace{}}{\stackrel{\sim}{0}}$ & $\begin{array}{l}1 \\
2 \\
3 \\
4 \\
5 \\
6 \\
7 \\
8 \\
9 \\
10\end{array}$ & $\begin{array}{l}\text { Transition } \\
\text { Transition } \\
\text { Transition } \\
\text { Immature } \\
\text { Mature } \\
\text { Formed } \\
\text { Transition } \\
\text { Formed } \\
\text { Transition } \\
\text { Immature }\end{array}$ & $\begin{array}{l}0 \\
3,56 \\
3.5 \\
7.32 \\
9,36 \\
6,89 \\
9,32 \\
11,78 \\
17.10 \\
16,3\end{array}$ & $\begin{array}{l}9.4 \\
9.43 \\
9,67 \\
10,12 \\
9.43 \\
8,79 \\
5.77 \\
9,41 \\
9.3 \\
7.32\end{array}$ & $\begin{array}{l}17.2 \\
12 \\
11.10 \\
12.73 \\
18.87 \\
15,21 \\
5.77 \\
11.76 \\
17.4 \\
21.95\end{array}$ & $\begin{array}{l}62.5 \\
72.1 \\
14.55 \\
46.7 \\
11.32 \\
12,45 \\
9.62 \\
15.7 \\
15.11 \\
17.1\end{array}$ & $\begin{array}{l}11 \\
46.2 \\
13,12, \\
18.20 \\
60 \\
12.10 \\
7,13 \\
38.46 \\
15.7 \\
14.3\end{array}$ & $\begin{array}{l}0.46 \\
0.49 \\
0.42 \\
0.43 \\
0.41 \\
0.65 \\
0.42 \\
0.46 \\
0.57 \\
0.52\end{array}$ & $\begin{array}{l}0.52 \\
0.37 \\
0.55 \\
0.52 \\
0,63 \\
0,66 \\
0,58 \\
0,60 \\
0,47 \\
0,56\end{array}$ & $\begin{array}{l}0.43 \\
0.16 \\
0.91 \\
0,78 \\
1,45 \\
0,35 \\
0,13 \\
1,76 \\
0,15 \\
0,86\end{array}$ & $\begin{array}{l}11 \\
16.2 \\
17 \\
13,1 \\
18,67 \\
5,4 \\
11,6 \\
15,3 \\
6,9 \\
5,8\end{array}$ \\
\hline$\frac{n}{\delta}$ & $\begin{array}{l}1 \\
2 \\
3 \\
4 \\
5 \\
6 \\
7 \\
8 \\
9 \\
10\end{array}$ & $\begin{array}{l}\text { Immature } \\
\text { Immature } \\
\text { Transition } \\
\text { Formed } \\
\text { Mature } \\
\text { Transition } \\
\text { Transition } \\
\text { Formed } \\
\text { Formed } \\
\text { Formed }\end{array}$ & $\begin{array}{l}20 \\
0 \\
0 \\
26 \\
15 \\
0 \\
19 \\
27 \\
6.3 \\
14\end{array}$ & $\begin{array}{l}22.2 \\
7.14 \\
0 \\
18 \\
10.42 \\
42 \\
35.3 \\
52.1 \\
0 \\
6\end{array}$ & $\begin{array}{l}13.3 \\
7.14 \\
22.20 \\
29.10 \\
3.77 \\
19,32 \\
9.62 \\
33.3 \\
15 \\
17.65\end{array}$ & $\begin{array}{l}35.6 \\
61 \\
72.41 \\
40,00 \\
25.45 \\
7.55 \\
9,23 \\
30.77 \\
23.53 \\
10.5\end{array}$ & $\begin{array}{l}9 \\
25 \\
28 \\
11.76 \\
31.25 \\
0 \\
17.65 \\
25 \\
11.76 \\
10,34\end{array}$ & $\begin{array}{l}0.26 \\
0.54 \\
0.620 \\
.24 \\
0.23 \\
0.57 \\
0,39 \\
0,53 \\
0,58 \\
0,52\end{array}$ & $\begin{array}{l}0.33 \\
0.53 \\
0.72 \\
0.42 \\
0.27 \\
0.56 \\
0,40 \\
0,47 \\
0,51 \\
0,49\end{array}$ & $\begin{array}{l}1.56 \\
0.24 \\
0,34 \\
1.4 \\
1.67 \\
0.32 \\
1,45 \\
1,2 \\
1,2 \\
0,3\end{array}$ & $\begin{array}{l}8.88 \\
25 \\
13,5 \\
5,9 \\
15,5 \\
31.25 \\
7.6 \\
9,67 \\
4,89 \\
4,1\end{array}$ \\
\hline
\end{tabular}

In studying the productivity, it is possible to get complete information about the plant resources and to determine the agricultural significance of the cenopopulations.It is not enough to study only cenopopulations in ths point.

Among the investigated species, Salvia sclarea is specially rich with valuable ether oil,greasy oil and vitamin $\mathrm{C}$, it is also used in perfumery, from this point of view, its productivity is determined.

The buds and the fruits of the plant are important,fully ripe fruits are used for the medical purpose, so its reserve is studied in budding,fruit formation and complete maturation phases( tab.4).

Table 4.Fitomass of the Salvia sclarea speciesin the different periods of ontogenesis

( dry weight,gr.)

\begin{tabular}{|c|c|c|}
\hline Age group & Surface fitomass & Seed \\
\hline$i m$ & $9,5 \pm 0.93$ & $2,32 \pm 0,52$ \\
\hline$v$ & $21.36 \pm 1.53$ & $3.33 \pm 3.56$ \\
\hline$g_{1}$ & $228 \pm 37.5$ & $11.7 \pm 1.27$ \\
\hline$g_{2}$ & $420.3 \pm 45.3$ & $18.5 \pm 2,65$ \\
\hline$g_{3} s$ & $381 \pm 37.2$ & $17.82 \pm 3.6$ \\
\hline$s s$ & $72.45 \pm 17.2$ & $7.53 \pm 2.7$ \\
\hline$s+11.2$ & $4.12 \pm 1.35$ \\
\hline
\end{tabular}

As to be seen from the table 4, the plant has most reserve in the generative growth period.

From the seeds of the plant, it is possible to get $0,3 \%$ of ether oil. So, from a hectare field,approximately, $1,5 \mathrm{~kg}$ ether oil is acquired, and it is used in the production of tons of fragrancy in the different compositions.

\section{References}

1. Ведерникова О.П. Популяционно-онтогенетический подход к оценке состояния биологических ресурсов лекарственных растений в Республике Марий Эл// Ботанические исследования в азиатской России. Барнаул, 2003. Т.3. С. 9-10.

2. Животовсий

Л.А. 


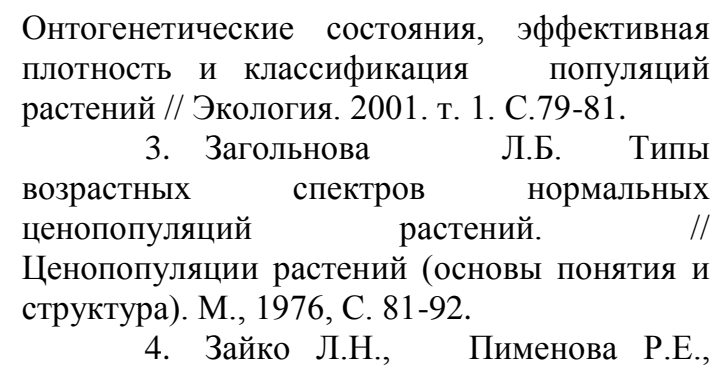
Масликов В.Ю. Обзор метода и результатов по изучению лекарственных растений России (По материалом ВИЛАР). Материалы Межд. Науч. - Прак. Конф. Современные проблемы фитодизайна. Белгород, 2007, с. 148-157.

5. Камелин Р.В. Флорогенетический анализ естественной флоры горной Средный Азии. -Л.: Наука, 1973, 354 с.

6. Каптен Ю.Л. К методике определение проективного покрытия в флорогенетических исследованиях. Вестн. Ленингр. ун-та, 1983, №3, т.6, с. 115-116

$$
\text { 7. Крылова И.Л. Ресурсная }
$$

характеристика лекарственных растений как научная основа их рациональной эксплуатации: Автореф. дис. ... д-ра биол. наук. М., 1985.

8. Крылова И.Я., Шретер А.И. Методические указания по изучению запасов дикорастущих лекарственных растении. М., ВИЛАР, 1971, с.21

9. Методика определения запасов лекарственных растений. М., 1986.

10. Работнов Т.А. Жизненный цикл многолетних травянистых растении в луговых ценозах. В кн.: Геоботаника, М.-Л.: 1950.

11. Флора Азербайджана, т.4, с. 324

12. Уранов А.А. Возрастной спектр фитоценопопуляций как функция времени и энергетических волновых процессов. // Науч. докл. высш. шк. Биол. науки. 1975. вып. 2. с. 7-33 //

13. Юрцева Б.А. Некоторые тенденции развития метода конкретных флор. Ботан. ж. 1975. -60, №1. с. 69-83 